UDC 621.039.51

V.V. Galchenko ${ }^{1}, \mathrm{PhD}$,

A.M. Abdulaev ${ }^{2}$,

I.I. Shlapak ${ }^{1}$

${ }^{1}$ RPA “Impulse-Kiev”, 17-A Verbova Str., Kiev, 04073, Ukraine, e-mail: v.galchenko@npp-osi.kiev.ua

${ }^{2}$ The Center for Reactor Core Design "Kharkov Institute of Physics and Technology" "Nuclear Fuel Cycle” Science and Technology

Establishment, 1 Akademicheskaya Str., Kharkov, 61108, Ukraine

\title{
USING SOFTWARE BASED ON THE MONTE CARLO METHOD FOR RECEIVING THE FEW-GROUP HOMOGENIZED MACROSCOPIC INTERACTION CROSS-SECTIONS
}

\begin{abstract}
В.В. Гальченко, А.М. Абдулаев, І.І. Шлапак. Використання програмного продукту на базі методу Монте-Карло для отримання малогрупових гомогенізованих макроскопічних перерізів взаємодії. При проведенні малогрупових розрахунків різних станів реакторної установки важливе значення мають питання підготовки малогрупових констант. Від того, як це було зроблено, залежить точність і якість подальших розрахунків кінетики реактора. Для підготовки малогрупових характеристик зазвичай використовуються транспортні програмні продукти (детерміністичні коди), які на основі теорії переносу нейтронів розраховують потоки нейтронів в залежності від енергії і положення в чарунці. Наведено опис розрахункової схеми ТВ3, для цілей підготовки малогрупових характеристик, для програмного продукту Serpent, який використовує метод Монте-Карло та безперервну за енергією бібліотеку мікроскопічних констант і який розроблено для розрахунку характеристик ТВЗ, включно з розрахунком вигоряння і підготовкою малогрупових гомогенізованих макроскопічних перерізів взаємодії, для розрахунку активної зони. Наведено розрахункову схему для програмного продукту Serpent для ТВЗА та результати порівняльних розрахунків основних нейтронно-фізичних характеристик з кодами PHOENIX-H i WIMSD5B.

Ключові слова: Serpent, PHOENIX-H, WIMS, комп’ютерні коди, ВВEР-1000, метод Монте-Карло, перерізи взаємодії, коефіцієнт розмноження

V.V. Galchenko, A.M. Abdulaev, I.I. Shlapak. Using software based on the Monte-Carlo method for receiving the few-group homogenized macroscopic interaction cross-section. The constant preparation issues are important for performing the few-group analysis for different states of the reactor core. Besides, the constant preparation method influences the further calculations accuracy and quality. The transport software products (deterministic codes) are usually used for the few-group characteristics preparation. On the basis of the neutron transport theory these codes calculate neutron fluxes depending on the energy and on the location in the cell. In present paper the description of fuel assembly calculation scheme for preparing the few-group characteristics is given for the Serpent code. This code uses the MonteCarlo method and energy continuous microscopic data library. Serpent code was developed for calculating the fuel assembly characteristics including burnup calculations and preparation of the few-group homogenized macroscopic interaction cross-sections for the core calculating. The calculation scheme for the Serpent code for FAA and the results of the basic neutron-physical characteristics comparative calculations with PHOENIX-H and WIMSD5B codes are presented.
\end{abstract}

Keywords: Serpent, PHOENIX-H, WIMS, computer codes, VVER-1000, Monte-Carlo method, cross-sections, multiplication factor

Introduction. Typically, the neutron-physical processes modeling is based on two main types of methods: deterministic methods and stochastic methods (for example, the Monte Carlo method). The neutron transport equations numerical solution lies in the basis of the deterministic methods (for example, the discrete ordinates method or the characteristic method). The Monte Carlo methods are based on analyzing the probabilities of many events by simulating millions of elementary particles for the given material characteristics and geometry. The Monte Carlo methods are the most suitable for modeling the critical systems with complex geometry, where the deterministic methods cannot be applied. The most famous computer code using the Monte Carlo method for calculating the reactor systems is the MCNP code, developed by the Los Alamos National Laboratory (LANL, USA) [11].

Recently other reactor codes based on the Monte Carlo method have actively been developing. Among them the Serpent code is distinguished [2]. This code has been developing since 2004 at the VTT Technical Research Center (Finland). It quickly ingratiated with many scholars all over the world

DOI:

(C) 2017 The Authors. This is an open access article under the CC BY license (http://creativecommons.org/licenses/by/4.0/). 
due to its convenience, accuracy of calculations and wide range of tasks that it is capable to solve. At present, the Serpent code is actively used for studying reactors both on "fast" and on "thermal" neutrons [3, 4].

Today Monte Carlo calculations are considered to be the most precise. Criticality calculations of different systems with fuel, as well as various radiation characteristics calculations are carried out using such codes. Another possibility to use software based on the Monte Carlo method is calculating the whole core characteristics.

However, calculating the core using codes based on the Monte Carlo method is still of a single nature. Mainly it is used for research purposes since it requires significant machine resources and system's modeling volumes.

Currently the core characteristics calculations are carried out using software that solves the reactor kinetic equations in a two-group approximation. The accuracy of this calculation depends greatly on the constant software preparation quality.

The Serpent computer code gives a possibility to prepare the few-group homogeneous macroscopic characteristics. In order to do this it is necessary to carry out the verification calculations of the developed calculation scheme for the corresponding fuel assembly (FA) beforehand.

\section{The VVER-1000 calculation scheme and the calculation methodology}

1.1 VVER-1000 FA calculation scheme. The fuel assembly main type, currently operated at the NPP with VVER-1000 in Ukraine, is TVSA. Project fuel loading, formed mainly from fuel assembly of several types, is 439MT and 398MO. The configurations of these FA are shown in Fig. 1

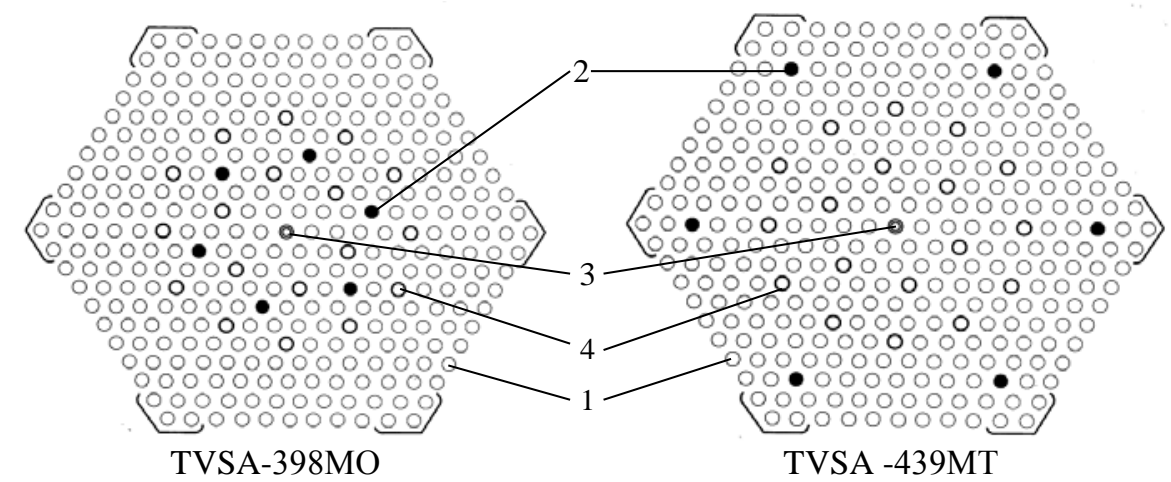

Fig. 1. Configuration of 398MO and 439MT fuel assemblies: fuel elements with 4,0\% enrichment on 235U (1); fuel elements with 3,3\% enrichment on $235 U$ and $5 \%$ Gd2O3 (2); central tube (3); instrumental tubes (4)

Table 1

Material and geometric characteristics of VVER-1000 FA

\begin{tabular}{l|c}
\hline Parameter & Value \\
\hline Fuel rods step in FA, cm & 1.275 \\
\hline Fuel & $\mathrm{UO}_{2}$ \\
\hline Fuel pill diameter, fuel rod internal / external, $\mathrm{cm}$ & $0.14 / 0.757$ \\
\hline Diameter of fuel shell, internal / external, $\mathrm{cm}$ & $0.772 / 0.91$ \\
\hline Material of fuel shell & $\mathrm{Zr}+1 \% \mathrm{Nb}$ \\
\hline Diameter of guide channels, internal / external, $\mathrm{cm}$ & $1.09 / 1.26$ \\
\hline Diameter of the central tube, internal / external, cm & $1.1 / 1.3$ \\
\hline Coolant temperature, $\mathrm{K}$ & 578 \\
\hline Coolant density, g/cm & 3 \\
\hline Fuel temperature, $\mathrm{K}$ & 0.723 \\
\hline Fuel rods fuel density, g/cm ${ }^{3}$ & 890 \\
\hline Boron concentration in the coolant, $\mathrm{ppm}$ & 10.45 \\
\hline
\end{tabular}

The TVSA geometric and material characteristics, which were used in modeling and further calculations, are presented in Table 1.

The Serpent code geometry is based on the structures similar to MCNP [2]. These structures are based on the Universe-based combinatorial solid geometry (CSG) model. The FA calculation schemes, which were developed for the Serpent code, are shown in Fig. 2 and Fig. 3. The drawings are built directly by the Serpent code from the input file. 


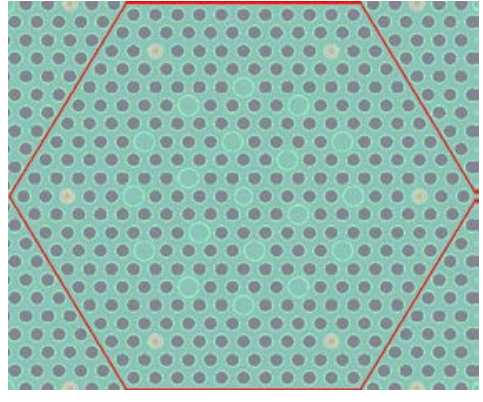

Fig. 2. 439MT FA calculation scheme for Serpent code

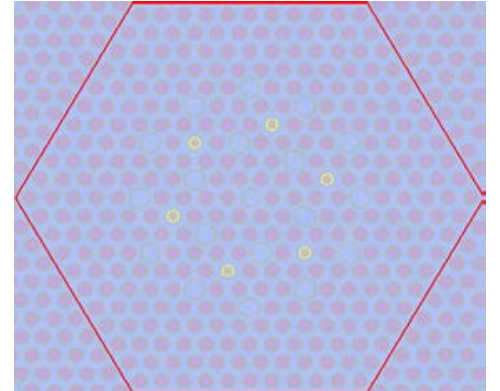

Fig. 3. 398MO FA calculation scheme for Serpent code

The VVER-1000 FA calculation schemes for the WIMSD5B [5] and PHOENIX-H [6] computer codes, as well as some verification calculations for them are presented in [6-9].

1.2 The Monte Carlo method in Serpent code. Serpent code uses an energy-continuum library of neutron-physical constants. In this research the library of neutron-physical constants, based on the evaluated nuclear data ENDF/B6.8 file, was used. Although, Serpent allows to use libraries based on other evaluated nuclear data files (e.g. JEF2.2 [10]). The implemented in Serpent, Monte Carlo method defines the neutron multiplication factor for the system as the ratio of the one generation's neutrons number to the previous generations' neutrons number. Thus, the neutrons flow interaction with the matter nuclei is "played out" directly in the program.

The difference between Serpent and MCNP is in the use of the "Woodcock delta-tracking" method for the neutron transfer modeling, unlike the traditional for the Monte Carlo codes "Surface-tosurface ray-tracing" method. The "Woodcock delta-tracking" method's main advantage is that it greatly simplifies the geometry processing during the calculation. It leads to a decrease in the modeling time, especially for complex geometry [11].

2. Calculations results. The calculation was made for the system parameters given in Table 1 with the burnup step of $1.5 \mathrm{MW}$-day/t(U) to $60 \mathrm{MW} \cdot d a y / t(\mathrm{U})$. In Fig. 4 and Fig. 5 the neutron multiplication factor dependence on the burnup, received by various codes, is presented.

The figures show that at the initial burnup stage the results between Serpent PHOENIX-H have rather high coincidence level. This is an integrated into Gd fuel burnup stage. Then the results for different codes are aligned. But the neutron multiplication factor obtained by Serpent is slightly lower than WIMSD5B and PHOENIX-H. Eventually at the end of the burnup they reach the same values. But the deviation between the neutron multiplication factor values concerning these three softwares does not exceed the value of $1.5 \%$.

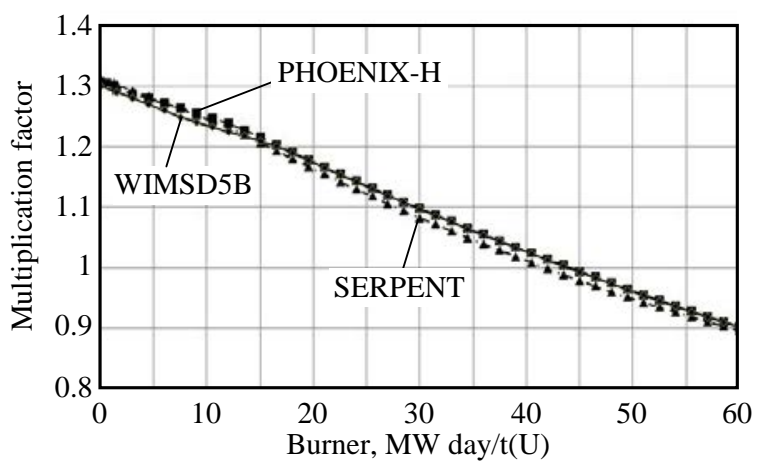

Fig. 4. Dependence of the neutron multiplication factor on the burnup for $439 M T$ FA

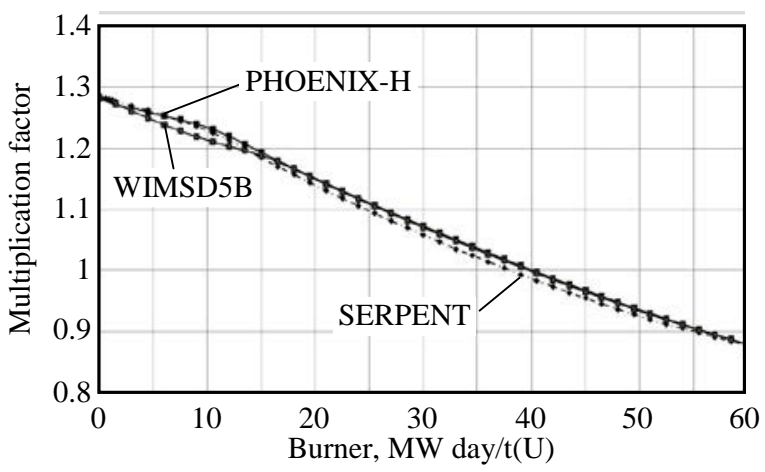

Puc. 5. Dependence of the neutron multiplication factor on the burn up for 398MO FA 
The main goal to use WIMSD5B and PHOENIX-H computer codes is few-group homogeneous macroscopic cross-section preparation. Tables 2-4 show the main interaction of cross-sections comparison in two energy groups.

Table 2

Main macroscopic interaction characteristics, counted using difference codes for 439MT FA, burnup $30 \mathrm{MW} \cdot \operatorname{day} / \mathrm{t}(\mathrm{U})$

\begin{tabular}{l|c|c|c}
\multicolumn{1}{c|}{ Parameter } & PHOENIX-H & WIMS & Serpent \\
\hline Diffusion coefficient for the 1st group $D_{1}, \mathrm{~cm}$ & 1.3968 & 1.4831 & 1.3024 \\
\hline Diffusion coefficient for the 2nd group $D_{2}, \mathrm{~cm}$ & 0.3911 & 0.3839 & 0.3768 \\
\hline Absorption cross-section for the 1st group $\Sigma_{a}^{1}, \mathrm{~cm}^{-1}$ & 0.0097 & 0.0098 & 0.0103 \\
\hline Absorption cross-section for the 2nd group $\Sigma_{a}^{2}, \mathrm{~cm}^{-1}$ & 0.1014 & 0.1039 & 0.1043 \\
\hline Multiplication capability for the 1st group $\cup \Sigma_{f}^{1}, \mathrm{~cm}^{-1}$ & 0.0075 & 0.0077 & 0.0081 \\
\hline Multiplication capability for the 2nd group $v \Sigma_{f}^{2}, \mathrm{~cm}^{-1}$ & 0.1681 & 0.1711 & 0.1731 \\
\hline For the 1st group $\chi \Sigma_{f}$ & 0.6124 & 0.6129 & 0.6469 \\
\hline For the 2nd group $\chi \Sigma_{f}$ & 14.1244 & 14.2209 & 14.3650 \\
\hline Multiplication factor & 1.3047 & 1.2983 & 1.3118 \\
\hline
\end{tabular}

As it can be seen from the tables the interaction cross-sections values in the "thermal" energy group have a rather high level of coincidence. A noticeable deviation occurs for the diffusion coefficient in the "fast" energy group. Although transport approximation was used for all three computer codes, Serpent has the lowest diffusion coefficient value in the "fast" energy group. It should be noted that this coefficient's magnitude does not affect further calculations significantly.

However, it must be noted that the calculation time (with all burnup points) for WIMSD5B/PHOENIX-H was about 2 minutes, while SERPENT spent an hour.

Conclusions. The relatively new Monte Carlo Serpent code, which can be used for the nuclear reactors neutron analysis, is presented. The main Serpent calculating capabilities are shown; VVER$1000 \mathrm{FA}$ is used as an example.

The further direction in the Serpent verification will be aimed at studying the calculating of homogeneous interaction cross-sections for VVER-1000 fuel methods and analyzing the microscopic constants libraries effects, since Serpent code makes it possible to use the microscopic constants library based on the evaluated nuclear data JEFF file.

Table 3

Main macroscopic interaction characteristics, counted using difference codes for 439MT FA, burnup $30 \mathrm{MW} \cdot \operatorname{day} / \mathrm{t}(\mathrm{U})$

\begin{tabular}{l|c|c|c}
\hline \multicolumn{1}{c|}{ Parameter } & PHOENIX-H & WIMS & Serpent \\
\hline Diffusion coefficient for the 1st group $D_{1}, \mathrm{~cm}$ & 1.4285 & 1.4777 & 1.3133 \\
\hline Diffusion coefficient for the 2nd group $D_{2}, \mathrm{~cm}$ & 0.3777 & 0.3734 & 0.3696 \\
\hline Absorption cross-section for the 1st group $\Sigma_{a}^{1}, \mathrm{~cm}^{-1}$ & 0.0108 & 0.0109 & 0.0113 \\
\hline Absorption cross-section for the 2nd group $\Sigma_{a}^{2}, \mathrm{~cm}^{-1}$ & 0.1020 & 0.1026 & 0.1085 \\
\hline Multiplication capability for the 1st group $v \Sigma_{f}^{1}, \mathrm{~cm}^{-1}$ & 0.0056 & 0.0058 & 0.0059 \\
\hline Multiplication capability for the 2nd group $v \Sigma_{f}^{2}, \mathrm{~cm}^{-1}$ & 0.1565 & 0.1568 & 0.1660 \\
\hline For the 1st group $\chi \Sigma_{f}$ & 0.4388 & 0.4469 & 0.4583 \\
\hline For the 2nd group $\chi \Sigma_{f}$ & 12.2950 & 12.1771 & 12.8255 \\
\hline Multiplication factor & 1.0985 & 1.0972 & 1.0832 \\
\hline
\end{tabular}


Main macroscopic interaction characteristics, counted using difference codes for 398MO FA, burnup $0 \mathrm{MW} \cdot \operatorname{day} / \mathrm{t}(\mathrm{U})$

\begin{tabular}{l|c|c|c}
\hline \multicolumn{1}{c|}{ Parameter } & PHOENIX-H & WIMS & Serpent \\
\hline Diffusion coefficient for the 1st group $D_{1}, \mathrm{~cm}$ & 1.39721 & 1.481411 & 1.29387 \\
\hline Diffusion coefficient for the 2nd group $D_{2}, \mathrm{~cm}$ & 0.39001 & 0.384645 & 0.37702 \\
\hline Absorption cross-section for the 1st group $\Sigma_{a}^{1}, \mathrm{~cm}^{-1}$ & 0.00946 & 0.009635 & 0.01001 \\
\hline Absorption cross-section for the 2nd group $\Sigma_{a}^{1}, \mathrm{~cm}^{-1}$ & 0.09602 & 0.097977 & 0.09901 \\
\hline Multiplication capability for the 1st group $v \Sigma_{f}^{2}, \mathrm{~cm}^{-1}$ & 0.00709 & 0.007269 & 0.00759 \\
\hline Multiplication capability for the 2nd group $v \Sigma_{f}^{2}, \mathrm{~cm}^{-1}$ & 0.15601 & 0.158997 & 0.16063 \\
\hline For the 1st group $\chi \Sigma_{f}$ & 0.5759 & 0.5776 & 0.6068 \\
\hline For the 2nd group $\chi \Sigma_{f}$ & 13.0987 & 13.2151 & 13.3340 \\
\hline Multiplication factor & 1.2818 & 1.2803 & 1.2853 \\
\hline
\end{tabular}

It is important to note that in order to use code for preparing a few-group constants software, a great number of verification calculations must be executed for multilateral investigation of all factors that influence the calculations result, since the further core calculations quality and accuracy depends on the constant software preparation.

\section{Література}

1. Briesmeister J. MCNP General Monte Carlo Code N-Particle Transport Code Version 4C, LA-13709-M. 1993. $790 \mathrm{p}$.

2. Leppänen J. PSG2/Serpent - a continuous-energy monte carlo reactor phisics burnup calculation code. Methodology. User's Manual. Validation report. Helsinki University of Technology. November 6, 2009.

3. Fridman E., Shwageraus E. Modeling of SFR cores with Serpent-DYN3D codes sequence. Annals of Nuclear Energy. 2013. Vol. 53. P. 354-363.

4. Fridman E., Leppänen J. On the use of the Serpent Monte Carlo code for few-group cross section generation. Annals of Nuclear Energy. 2011. Vol. 38. P. 1399-1405.

5. A general description of the lattice code WIMS / J.R. Askew et al. Journal of the British Nuclear Energy Society. 1966. 5 (1). P. 564-584.

6. Математическое моделирование радиационных процессов в реакторных установках. /В.В. Ган та ін. Вопросы атомной науки и техники. Харьков, 2009. №2 (93). С. 135-144.

7. Comparison of the APA-H (Westinghouse) calculations with the operational data for ZPNPP Unit №3 Cycles 16 19. / A.M. Abdullayev, et al. Comparison. Proceedings of 17th Symposium of AER on VVER Reactor Physics and Reactor Safety. September 24-29. 2007. Yalta. Crimea.

8. Гальченко В.В. Сравнительный анализ подготовки данных с использованием различных компьютерных кодов. Часть 2. Ядерні та радіаційні технологї̈. Київ, 2007. т. 7 (№3-4). С. 29-42.

9. Гальченко В.В., Мішин А.А. Порівняльний аналіз нейтронно-фізичних характеристик кампанії реактора 3 використанням різних наборів бібліотек ядерних даних для програмного продукту WIMSD5B. Ядерна та радіачійна безпека. Київ, Вип. 3(67). 2015. С. 8-12.

10. Інтернет-сторінка коду Serpent. URL: http://montecarlo.vtt.fi/ (дата звернення 18.05.16).

11. The Serpent Monte Carlo code: Status, development and applications in 2013/ Leppänen J. et al. Annals of Nuclear Energy. 2015. Vol. 82. P. 142-150.

\section{References}

1. Briesmeister, J. (1993). MCNP General Monte Carlo Code N-Particle Transport Code. Version 4C. LA-13709-M.

2. Leppänen, J. (2009). PSG2/Serpent - a continuous-energy monte carlo reactor phisics burnup calculation code. Methodology. User's Manual. Validation report. Helsinki University of Technology, November 6. 
3. Fridman, E., \& Shwageraus, E. (2013). Modeling of SFR cores with Serpent-DYN3D codes sequence. Annals of Nuclear Energy, 53, 354-363.

4. Fridman, E., \& Leppänen, J. (2011). On the use of the Serpent Monte Carlo code for few-group cross section generation. Annals of Nuclear Energy, 38, 1399-1405.

5. Askew, J.R. \& et al., (1966). A general description of the lattice code WIMS. Journal of the British Nuclear Energy Society, 5 (1), 564-584.

6. Gann, V.V., Abdullayev, A.M., \& Zhukov, A.I. et al. (2009). Computer simulation of radiation processes in reactor ficilities. Problems of atomic science and technology. Kharkiv, 2(93), 135-144.

7. Abdullayev, A.M., Gorbachenko, O.V., \& Ignatchenko A.I. et al. (2007). Comparison of the APA-H (Westinghouse) calculations with the operational data for ZPNPP Unit №3 Cycles 16 19. Comparison. Proceedings of 17th Symposium of AER on VVER Reactor Physics and Reactor Safety. September 2429, Yalta, Crimea.

8. Galchenko, V. (2007). Data preparation comparison analysis using difference computer codes. Part 2. Nuclear and radiation technologies, 7 (№ 3-4), 29-42.

9. Galchenko, V., \& Mishyn, A. (2015). Comparative analysis of reactor cycle neutron characteristics using different WIMSD5B nuclear data libraries. Nuclear and Radiation Safety, 3 (67), 8-12.

10. Serpent code internet page, http://montecarlo.vtt.fi/ (actual on 18.05.16).

11. Leppänen, J., Pusa, M., \& Viitanen, T., et al. (2015). The Serpent Monte Carlo code: Status, development and applications in 2013. Annals of Nuclear Energy, 82, 142-150. 